\title{
New Development of T\&I Education in China
}

\author{
Lidi Wang* \\ Beijing Foreign Studies University \\ Xisanhuan Beilu, Beijing, China Postal Code, 100089
}

Received 18.10.2015, received in revised form 24.12.2015, accepted 07.02.2016

Translator and interpreter (T\&I) studies flourished in the past decade in China's higher education, both at the postgraduate level and at the undergraduate level. The fast development was mainly driven by the following external and internal factors. Compared with more well-established disciplines, T\&I studies is still at its fledgling stage in China's higher education. There are a lot to be done in terms of promoting best practices of teaching, combining classroom training with more real-world professional practices, teacher training, application of new technologies and research input. Traditional foreign language teaching programs have fallen short of the societal demand for professional language service and new ways of teaching and learning foreign languages to make such efforts more effective and applicable must be encouraged. Introducing T\&I studies at the undergraduate level represents such a move in the right direction. Moreover, T\& I training opens up the possibility of making the teaching and learning activities more content-rich and more relevant to what people are most concerned about in contemporary society. To make the teaching effective and yielding the expected learning outcomes, a well-balanced curriculum needs to be put in place, combining liberal education, English language enhancement and core courses for translation and interpreting studies including the knowledge and skills for carrying out translation and interpreting assignments. Like any other scientific discipline, constant research input is needed for the healthy development of T\&I studies. To make the T\&I program successful, one needs to strike a balance between practice and research.

Keywords: translation, interpreting, trasnslation studies, education.

DOI: 10.17516/1997-1370-2016-9-3-612-619.

Research area: philology.

The past decade has witnessed a boom of translator and interpreter training programs in China's higher education, both at the postgraduate level and at the undergraduate level. As of the end of 2015 there are all together 206 postgraduate programs (MTI) in translator and interpreter (T\&I) studies and 150 undergraduate programs in China's universities. The fast development was mainly driven by the following external and internal factors. First, as a result of globalization in economics and other spheres of life, there has been increased communication among people speaking different languages and China's socio-economic development in the past decades have given rise to greater needs for professional language service. With more and more Chinese enterprises going offshore, the shortfall of trained language professionals who can deliver quality service is keenly felt.

(C) Siberian Federal University. All rights reserved

* Corresponding author E-mail address: wanglidi@bfsu.edu.cn 
According to statistics released by BOSI, the global production value of translation service reached 37.2 billion USD by the end of 2014 and it is projected to reach 53 billion USD by the year 2020.

The latest release from Ministry of Commerce (MOC), China's direct investment overseas hit 118 billion USD in 2015, representing $14.7 \%$ increase against the previous year. The average increase of the direct investment overseas in the last 13 years stands at $33.6 \%$ and the accumulated investment overseas as of the end of 2015 is worth more than 1 trillion USD. Under the "one belt, one road" initiative, China has had its direct investment in 49 countries covering transportation, power supply, communication and other equipment. All these investment and activities offshore need to be supported with language service by professionally trained translators and interpreters.

Secondly, the number of young people graduating from universities has been rising each year since 2001 as a result of the increase of students enrolled into universities and the number has reached over 7,000,000 in the last couple o years, which makes the job market extremely competitive and exerts great pressure on students graduating from universities. Out of necessity, many of them choose to continue to further their studies by enrolling in Master's degree programs, and they would opt for programs that offers the best chance of making them more competitive on the job market. Graduates with a perfect mastery of foreign languages and particularly those who have acquired the professional skills of doing translation and/or interpreting are very much sought after by government offices and enterprises doing businesses overseas.

In addition to these external factors, there are also factors within China's higher education and its foreign language education in particular that had created this shortfall in the supply of qualified foreign language service. There are around 1000 foreign language teaching programs out of 2000 universities across the country now, but the traditional way of teaching foreign languages, focusing on literature and linguistic theory does little help when it comes to offering language service to meet the need of the market.

Therefore, the turn from foreign language studies to the training of language service providers is driven by market forces and it provides the opportunities for rethinking and revamping of foreign language education in China. It is a very complex process both at the macro and the micro-levels. At the national

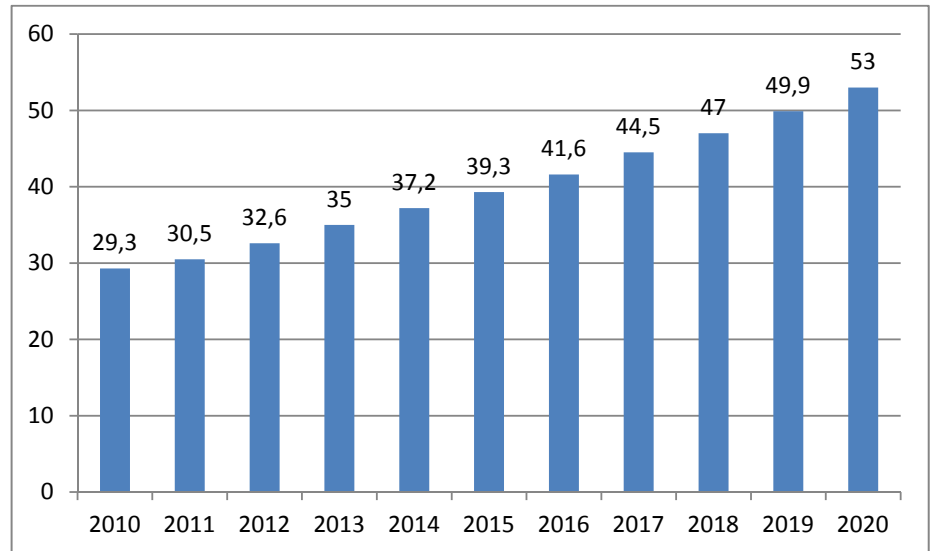

Fig. 1. World Translation Production 2010--2020, in billion USD, Data: SIBO 


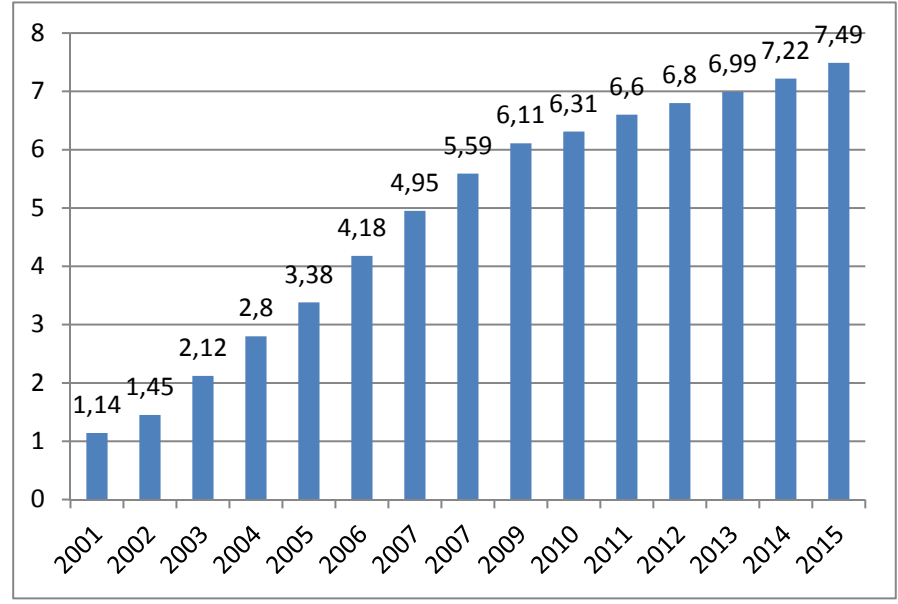

Fig. 2. Graduates from universities in China 2001-2015 in millions, Data: MOE

level, universities differ greater in terms of the resources they have, the faculty for carrying out the teaching and research, the academic performance of the students attending these programs. At the level of individual programs, people need to identify their teaching objectives, to come up with an appropriate curriculum for the training, to adopt teaching practices that would produce the expected learning outcomes and other innovative measures such as involving practicing professionals in the training process.

Compared with more well-established disciplines, T\&I studies is still at its fledgling stage in China's higher education. There are a lot to be done in terms of promoting best practices of teaching, combining classroom training with more real-world professional practices, teacher training, application of new technologies and research input. The National Steering Committee for Professional T\&I Education together with Translator Association of China (TAC) have initiated a Summer Training Program for the last decade, attracting 200-300 teachers nation-wide to attend these events each year. The Steering Committee has also completed two rounds of national level appraisal of the Master's degree programs of translator and interpreter training
(MTI) in the last five years, covering $80 \%$ of all such programs. The Ministry of Education (MOE) and the Ministry of Human Resources and Social Security (MHRSS) sponsored two national level accreditation examinations for translators and interpreters in 2003 and 2005 respectively. The Accreditation Examinations administered by HHRSS coverings six foreign languages, including English, Russian, French, Spanish, German and Japanese and attracts more than 50000 people to sit for these exams, which has an increasing washback effect on universities teaching programs.

The setting of the Master's degree programs for T\&I studies (MTI) in 2008 was met with enthusiasm by universities, for there were only a couples of such taught programs by that time across the country and the market need was tremendous. In less than ten-year's time, there are more than two hundred MTI programs all over the country.The setting-up of T\&I training programs at the undergraduate level has been controversial from its very start. Those who criticize the move believe that the undergraduate studies at universities should focus on enhancing the young students' language competence and scope of knowledge rather than teaching specific skills of 
performing translation and interpreting. Those who support the setting-up of undergraduate programs for T\&I studiesbase their stand on the following arguments:

- Traditional teaching methods are out of date and out of touch with the reality;

- The general foreign language proficiency of students entering foreign language programs are much higher than before and T\&I studies are more demanding than language learning;

- T\&I studies helps students to become a good learner of different knowledge areas and a good communicator with other people;

- A four-year undergraduate program is capable of providing a solid foundation for the learners to perform translation/ interpreting and other types of language service.

- Language learning is for self-improvement while T\&I studies aims at providing marketable service;

- T\&I training provides a new orientation for language learning and equips the learners with professional skills that make them more competitive on the job market;

Traditional foreign language teaching programs have fallen short of the societal demand for professional language service and new ways of teaching and learning foreign languages to make such efforts more effective and applicable must be encouraged. Introducing T\&I studies at the undergraduate level represents such a move in the right direction. Moreover, T\&I training opens up the possibility of making the teaching and learning activities more content-rich and more relevant to what people are most concerned about in contemporary society, be it the environmental issues, new forms of energy, economics and finance, public health or international relations.
Such exposure not only enhances the learners' language abilities but also their sense of awareness as an active member of the society. It also broadens the horizon of the learners and make them knowledge-savvy learners of different sphere of life and domains of knowledge.

To make the teaching effective and yielding the expected learning outcomes, a well-balanced curriculum needs to be put in place, combining liberal education, English language enhancement and core courses for translation and interpreting studies including the knowledge and skills for carrying out translation and interpreting assignments. For each of the courses in translation and interpreting, they differ in terms of aims and focus of teaching, of the course; but there are certain features of these courses that distinguish them from traditional language teaching. These courses are generally skill-based and practiceoriented, aiming at fostering the different skills required for accomplishing the translation or interpreting tasks through many hours of handon practice both in class and outside the class. The content of the teaching and materials used are not textbook based, but are mostly taken from recently published authentic materials on topics of wide public interest; and such materials usually cover a wide range of topics of different knowledge domains. To accomplish these tasks, students have to spend a lot of time gathering relevant knowledge, information, vocabulary and parallel texts, which enhance their abilities to become quick learners and to broaden their scope of knowledge.

Let me demonstrate this with some concrete examples. Table 1. Includes a list the topics that has been used for the MA foundation course on Chinese-to-English Translation in the fall of 2015, which reflects the principles and features just mentioned above. The same principles are applicable to undergraduate T\&I teaching, in order to enhance the learners'abilities to use languages 
Table 1. Topics for Chinese- English translation assignments

\begin{tabular}{|c|c|c|}
\hline Week & Area & Topic \\
\hline & Social development & \\
\hline 1 & & China's Medicare \\
\hline 2 & & Social Welfare \\
\hline 3 & & Care for Aged \\
\hline \multirow[t]{2}{*}{4} & & Protecting Female Workers \\
\hline & Environment \& energy & \\
\hline 5 & & Winter Olympics 2022 \\
\hline 6 & & The Shale Gas Revolution \\
\hline 7 & & New Forms of Renewable Energy \\
\hline 8 & & $\begin{array}{l}\text { U.S.-China Joint Announcement on Climate } \\
\text { Change }\end{array}$ \\
\hline \multirow[t]{2}{*}{9} & Mid-term test & Report on Legal Aids over the Last Decade \\
\hline & Economics \& financing & \\
\hline 10 & & Middle Income Trap \\
\hline \multirow[t]{2}{*}{11} & & Global Service for Offshore Financing \\
\hline & Global issues & \\
\hline 12 & & UN Report on Mellanium Goals \\
\hline 13 & & The Fight against Terrorism \\
\hline 14 & Final test & $\begin{array}{l}\text { Reforms in Energy Sector Brings about More } \\
\text { Dynamism }\end{array}$ \\
\hline
\end{tabular}

in authentic contexts with real purposes and to enlarge their knowledge base in becoming a generalist as a translator or interpreter and a good learner as a language professional in the future. The 12 assignments and 2 tests for the course covers four broad areas: (1) social development, (2) environmental and energy issues, (3) economics and finance and (4) international relations. All the texts used were taken from articles published in Chinese newspapers and journals weeks and even just days before the classes took place. Both the teacher and the students would have to delve into related materials and parallel texts for better understanding and target text representations as if they were completing authentic translation assignments. These exercises have proven to be effective ways of delivering the knowledge and skills the course is set to achieve and form an indispensable part of the learning process. By the end of a four-month training, most students have shown perceivable progress and a satisfactory learning curve as shown by the charts in Fig. 3.

On the onehand, translationand interpreting skills represent "procedural knowledge" as against "factual knowledge" and the former can be acquired only through many long hours of practice. On the other hand, translation and interpreting are very complex mental activities that scientists are only beginning to understand with advanced technology. Ida (2001) says: "Translating is a complex and fascinating task. In fact, I. A. Richards (1953) has claimed that it is probably the most complex type of event in the history of the cosmos." Like any other scientific discipline, constant research input is needed for the healthy development of T\&I studies. To make the T\&I program successful, one needs to strike a balance between practice 


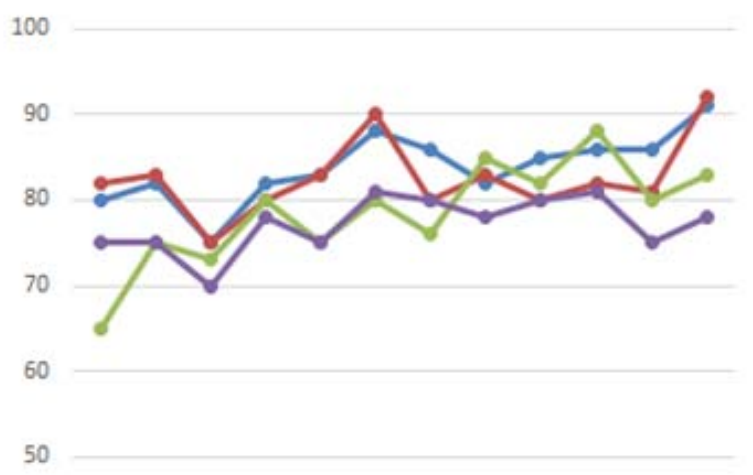

Fig. 3. Learning curve of 4 students for FRA5101

and research, and this is particular true for teacher development. And to become a qualified trainer for T\&I studies, one must possess a set of composite skills for practicing the trade, but also the knowledge and know-how for carrying out research in the related areas, without which one quickly finds oneself being marginalized in the academia and have little chance of survival in a research-led university habitat. Therefore, research is not something that is irrelevant for T\&I training but it is an essential part of a fullfledged program for translation and interpreting studies. For our future development, we envision a three-tiered T\&Itraining for higher education, with a proper focus or division of labor, so to speak. The four-year undergraduate program aims at laying a solid knowledge and skill foundation; while the MA degree program focuses on delivering professional quality language service. Finally, the Doctoral degree programs for translation and interpreting studies (DTI) yet to be established will be research-oriented and aims at developing the research skills that are necessary for knowledge innovation and scientific progress. Existing $\mathrm{Ph}$.D. programs for translation studies are often dominated by literary and historical studies are less relevant to the pressing needs of language service of the society at large. The new DTI program will be more concerned about the language service industry particularly for the fast growing manufacturing sector and its overseas development, communicating and understanding of China's cultural traditions and about the pedagogical issues involved in the process of translator and interpreter training.

Finally, it would be incomplete for any discussion about translation studies without mentioning the fast development of the application of communication technologies such as machine translation (MT) and computer aided translation (CAT) in China today. Apart from translation software such as SDL Trados and Déjà $\mathrm{Vu}$, quite a number of Chinese companies have developed their own CAT software packages or platforms, such as Huawei and China Publishing and Translation Corporation. These Chinese companies have gone into partnership with universities in providing training in related areas, offering language service to the market and in jointly carrying out research projects. With the emergence of big data management and other new technologies, technology-led translation studies is become a new trend for the development of the discipline and for the language service industry as a whole. According to the latest report released by China Translation Research Center, the 
following trend of development for IT-based translation service is worth noticing in the near future:

1. Increase in the demand for language service from mobile phones;

2. More applications for machine translation (MT), which will become part of the infrastructure of many applications;

3. Greater application o f multilingual speech recognition for human /machine interface;
4. More on-demand language service request from users;

5. Better translation quality supported by big data.

University education in T\&I studies need to take the fast development of IT-based language service into account in its curriculum design, training practices and its learning output to make sure that the people who enter these programs are better prepared to meet the challenge of the future.

\section{References}

China Translation Research Center and YeeCloud (2016) YeeCloud Language Service Big Data Report 2015.

Feng, Q. (2016). China Direct Overseas Investment Growth in 2015, in Economics Daily 2016/01/16.

Gile, D. (2009). Basic Concepts and Models for Interpreter and Translator Training (2nd Edition. Amsterdam and Philadelphia: JohnBenjamins Publishing Company.

Kelly, D. (2005). A Handbook for Translator Trainers.Manchester, UK \& NorthamptonMA:St Jerome Publishing.

Kiraly, D. (2000). A Social Constructivist Approach to Translator Education; Empowerment from Theory to Practice. Manchester, UK \& Northampton MA:St Jerome Publishing.

Nida, E. A. (2001). Language and Culture: Contexts in Translating. Amsterdam and Philadelphia: John Benjamins Publishing Company.

Richards, I. A. (1953) Toward a Theory of Translating, in Studies in Chinese Thought, ed. By Arthur F. Wright, 247-262. American Anthropological Association, vol. 55, Memoir 75. Chicago: Chicago University Press.

Wang, L. (2015). T \&I Training and Post-Tertiary Higher Education, Paper presented at the International Forum on T\&I Training in Beijing, 12, 2015.

Wang, L. (2012a). A Global Vision: Development of Translation and Interpreting Training, co-edit with H. Lee-Jahnke and M. Forstner, Foreign Language Teaching and Research Press, Beijing.

Wang, L. (2012b). A More Inclusive Model of Translator and Interpreter Training, in A Global Vision: Development of Translation and Interpreting Training, H. Lee-Jahnke, M. Forstner and Lidi Wang (editors) Foreign Language Teaching and Research Press, Beijing, 55-65,

Wang, L. (2011). Development of China's T\&I Studies in the First Decade of the New Century and Beyond, in Peter A. Schmitt, Susann Herold and Annette Weilandt (eds), Translationsforschung Tagungsberichte der LICTRA 2010, 899-903. 


\section{Новое развитие}

\section{переводческого образования в Китае}

\section{Лиди Ван}

Пекинский университет иностранных языков КНР, 100089, Пекин, Сисаньхуань Бэйлу

\footnotetext{
Перевод и переводоведение в последние десятилетия в Китае особенно активно развивались в области высшего образования как на уровне аспирантуры, так и на уровне бакалавриата и магистратуры. В статье автором последовательно анализируются внешние и внутренние факторы, которые повлияли на развитие перевода и переводческого образования в Китае в иелом.

Ключевые слова: перевод, переводоведение, переводческое образование, переводческая пратика.

Научная специальность: 10.00.00 - филологические науки.
} 